\title{
Study on the production of Reference Material (RM) for Vitamin B1, B2, B6 in health supplements
}

\author{
Nguyen Thi Hang*, Le Thi Phuong Thao, Dang Huu Cuong, \\ Luu Thi Huyen Trang, Le Thi Hong Hao \\ National Institute for Food Control, Hanoi, Vietnam
}

(Received: 22/10/2021; Accepted: 27/12/2021)

\section{Abstract}

Vitamins are essential nutrients commonly found in food products in general and health supplements in particular. In order to accurately evaluate product quality, laboratories need to use reference material in analysis, proficiency assessment, method validation and ensure the validity of the results. The use of reference materials plays an important role in the quality control of test results and is a mandatory requirement for laboratories wishing to demonstrate appropriate competence as required by ISO/IEC 17025:2017. The need to provide reference materials for laboratories is huge. However, at present, there are very few domestic organizations that can produce reference materials, while the cost of buying reference materials from reputable firms in the world is expensive. In this study, we introduced the procedure and production reference materials for the analysis of B-group vitamins (B1, B2, B6). These reference materials were evaluated for homogeneity and stability in 322 days. The certified values are consistent with the concentrations of substances present in normal samples in practice. The measurement uncertainty ranges from $14.5-23.3 \%$. The reference materials can be used for internal quality control for domestic laboratories and is also a premise for further research on standard samples with different matrix and analytical criteria. food.

Keywords: Reference material, reference material production, vitamin B1, B2, B6, health supplement

\section{INTRODUCTION}

As society develops, health issues are more concerned, so health supplements are also increasingly popular in the consumption habits of consumers. Health supplements include vitamins, minerals, biologically active ingredients, or foods prepared from herbs to maintain, enhance and improve the functions of the human body. Currently, there are many types of health supplements on the market that are produced domestically and imported from abroad. Among them, B-group vitamin supplements appear more and more widely, which is a favorite product of consumers. The inspection and evaluation of the ingredients of health supplements products become more and more urgent. In order to help the laboratories validate the method for determining vitamins and accurately determine test results, a quality control sample of the results is required.

Reference material is one of the tools used to ensure test results' validity and help laboratories evaluate the proficiency, accuracy, and reliability of test results [1]. It is also one of the mandatory criteria for laboratories who want to demonstrate their competence to an assessment organization that accredits compliance with the requirements of ISO/IEC 17025 [2] and management agencies in the assessment. Laboratories can choose from many methods to ensure the validity of test results, such as participation in proficiency testing, interlaboratory comparison, using reference material or internal quality control samples. Participation in proficiency testing or interlaboratory comparisons is sometimes not possible with laboratories due to objective conditions such as insufficient funding for participation, no supplier or program that is appropriate for the background. Therefore, using reference material or quality control samples is one of the good options for laboratories. However, there are very few organizations in Vietnam that can produce reference materials, while their demand in laboratories is enormous. 
Therefore, as an arbitration laboratory, we research and produce reference material of health supplements under the management of the Ministry of Health to ensure the use-value of test results serving operations at the unit and providing them to lower-level laboratories under the management of the Ministry

\section{MATERIALS AND METHODS}

\subsection{Materials}

Raw materials for producing healthy supplement samples include Vitamin B1, B2, B6 (made in China, imported Linh Hung Co., Ltd), Talc powder, Magnesium stearate (made in China, imported). Linh Hung Co., Ltd.), tapioca starch (manufactured and distributed by Truong Phat Production Trading Service Joint Stock Company), empty gelatin capsules, capsule size 00, manufactured by Pharmaceutical Joint Stock Company Kowloon. The materials were tested and evaluated following the certificate of analysis.

The bottle selected to store samples was HDPE (manufactured by Giang Ha Anh Co., Ltd.) that meets the requirements prescribed in QCVN 12-1:2011/BYT [3].

\subsection{Chemicals}

Standard materials were purchased from Sigma, including Vitamin B1 (Thiamin.HCl form) code 47858, lot LRAC2207, purity 99\%, Vitamin B2 (Riboflavin) code 47861, lot IRAC5854 purity 98.1 \% Vitamin B6 (Pyridoxin. $\mathrm{HCl}$ ) code 47862, lot LRAC4191 99.9\% purity. They were used in analysis to evaluate sample homogeneity and stability. In addition, chemicals used in the study (potassium dihydro phosphate, sodium heptane sulfonate, acetonitrile) were obtained from Merck. Other laboratory chemicals were purchased from reputable brands and achieved high purity needed for research.

\subsection{Equipment}

Sample analysis for homogeneity and stability was evaluated using a high performance liquid chromatography (Shimadzu LC-20), a PAD detector with wavelengths from 190 - $800 \mathrm{~nm}$. We used a vibrating screener, a cube mixer, a capsule filling machine, a sealing and capping machine, and some other common equipment and instruments of the laboratory to create samples.

\subsection{Methods}

\subsubsection{Sample production}

The health supplements were ground to reduce particle size. It was then sifted to obtain ingredients of the same size and greater uniformity. Material mixing is best done with similar substrates and according to the principle of homogeneity [4]. Then, the sample was homogenized, divided, packed in tablets/boxes [5]. Pursuant to Circular No. 43/2014/TT-BYT dated November 24, 2014 [6], for the target group of 7 - 9 years old, the content of vitamins B1, B2, B6 are expected with concentrations of $0.8-1.2 \mathrm{mg} / \mathrm{tablet}(500 \mathrm{mg} /$ tablet), equivalent to $160-240 \mathrm{mg} / 100 \mathrm{~g}$. The specific sample production process is presented in Figure 1.

\subsubsection{Evaluation of homogeneity and stability}

From the batch of samples generated, 10 samples were randomly selected and analyzed the content of vitamin B. Then, we assessed whether the difference between the results is statistically significant or not to conclude the homogeneity [7-8].

Evaluation of stability over time: Samples were stored at $25 \pm 5^{\circ} \mathrm{C}$ in the sample storage room of the Department of Quality Assurance. During the period from the date of manufacture to nine months, three or two random samples are taken every month, at least two samples are taken every three months, testing and evaluating the results [7].

Evaluation of stability by accelerated aging and time estimation: Samples were kept in a microclimate for accelerated aging at $45 \pm 2^{\circ} \mathrm{C}$, periodically take at least two test samples every month, evaluate the stability of the sample [7].

Analysis of samples to determine the content of Group B vitamins according to the method of the National Institute for Food Control, which has been recognized in accordance with ISO/IEC 17025. 


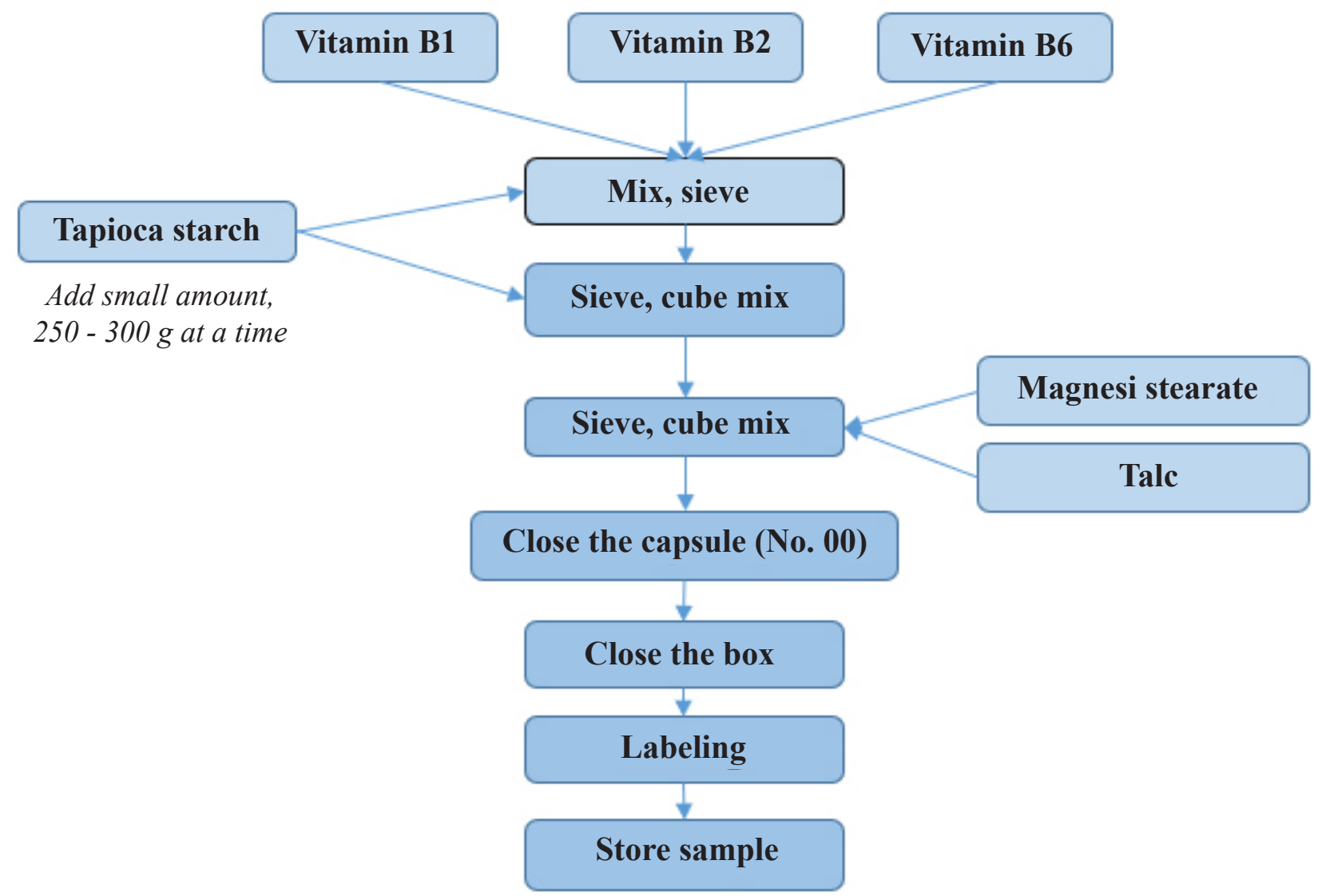

Figure 1. The process of producing reference material of vitamins in the health supplement

2.4.3. Determination of the assigned value and the measurement uncertainty of the reference value

The certified value was determined by sending the samples to 17 qualified laboratories. Seventeen obtained values were processed to remove raw values by a single Grubb test. The assigned value was calculated as follows [7]:

In which: $\quad x_{R M}$ : assigned value

$$
\mathrm{x}_{\mathrm{RM}}=\frac{\sum \mathrm{x}_{\mathrm{i}}}{\mathrm{p}}
$$

xi: value obtained from the laboratory $i$

p: number of laboratories

The uncertainty of the assigned value was expressed as characteristic uncertainty, homogeneity uncertainty, and stability uncertainty and was calculated as follows [7]:

$$
\mathrm{u}_{\mathrm{CRM}}=\sqrt{\left(\mathrm{u}_{\text {char }}^{2}+\mathrm{u}_{\text {hom }}^{2}+\mathrm{u}_{\mathrm{lts}}^{2}\right)}
$$

In which: $\quad u_{C R M}$ : uncertainty of certified value

$u_{\text {char }}:$ characterization uncertainty

$u_{\text {hom }}:$ homogeneity uncertainty

$u_{l t s}:$ stability uncertainty

\subsubsection{Data analysis}

$\mathrm{R}$ software was used to evaluate the single-factor analysis of variance (ANOVA), the homogeneity, F-test, and T-test to evaluate stability, and Microsoft Excel was used to evaluate the long-term stability and Determination of the assigned value, measure the uncertainty of the assigned value [7-8]. 


\section{RESULTS AND DISCUSSIONS}

\subsection{Sample production}

Following the given prototyping process and the Circular No. 43/2014/TT-BYT dated 24/11/2014 [6], a sample batch of 202 jars of health supplement $\times 30$ tablets/jar $\times 500 \mathrm{mg} /$ tablet was created.

\subsection{Evaluation of Homogeneity}

After creating a sample batch, the samples were sorted and numbered from one to the end in ascending order. We selected ten random samples to analyze and evaluate the homogeneity. The results of the analysis and assessment of the homogeneity of samples are given in Table 1.

Table 1. Test results to evaluate the homogeneity of Vitamins B1, B2, B6 content in the produced sample

\begin{tabular}{|c|c|c|c|c|c|c|c|}
\hline \multirow{3}{*}{ No } & \multirow{3}{*}{ Sample } & \multicolumn{6}{|c|}{ Amount (mg/100g) } \\
\hline & & \multicolumn{2}{|c|}{ Vitamin B1 } & \multicolumn{2}{|c|}{ Vitamin B2 } & \multicolumn{2}{|c|}{ Vitamin B6 } \\
\hline & & $1^{\text {st }}$ & $2^{\text {nd }}$ & $1^{\text {st }}$ & $2^{\text {nd }}$ & $1^{\text {st }}$ & $2^{\text {nd }}$ \\
\hline 1 & 87 & 265 & 265 & 133 & 142 & 258 & 265 \\
\hline 2 & 52 & 257 & 264 & 146 & 141 & 254 & 250 \\
\hline 3 & 103 & 275 & 255 & 142 & 145 & 276 & 259 \\
\hline 4 & 22 & 262 & 275 & 142 & 142 & 263 & 280 \\
\hline 5 & 130 & 247 & 255 & 155 & 148 & 247 & 247 \\
\hline 6 & 89 & 250 & 252 & 167 & 151 & 230 & 249 \\
\hline 7 & 127 & 245 & 252 & 170 & 155 & 245 & 240 \\
\hline 8 & 175 & 252 & 250 & 161 & 156 & 243 & 246 \\
\hline 9 & 120 & 252 & 249 & 151 & 165 & 251 & 240 \\
\hline 10 & 185 & 255 & 250 & 168 & 151 & 265 & 239 \\
\hline
\end{tabular}

Using one-factor ANOVA analysis of variance in R software, P-values $>0.05$ were obtained. Therefore, the difference between the samples is not statistically significant. Samples achieved homogeneity of Vitamin B1, B2, and B6 content.

\subsection{Evaluation of Stability}

Samples were evaluated for stability under two conditions: at room temperature and humidity controlled in a microclimate. 


\subsubsection{Room temperature condition}

The results of the stability analysis were given in Table 2.

Table 2. The test result of stability

\begin{tabular}{|c|c|c|c|c|c|c|}
\hline \multirow{3}{*}{ Days } & \multicolumn{6}{|c|}{ Amount (mg/100g) } \\
\hline & \multicolumn{2}{|c|}{ Vitamin B1 } & \multicolumn{2}{|c|}{ Vitamin B2 } & \multicolumn{2}{|c|}{ Vitamin B6 } \\
\hline & $1^{\text {st }}$ & $2^{\text {nd }}$ & $1^{\text {st }}$ & $2^{\text {nd }}$ & $1^{\text {st }}$ & $2^{\text {nd }}$ \\
\hline \multirow{6}{*}{48} & 257 & 255 & 151 & 154 & 243 & 248 \\
\hline & 248 & 247 & 141 & 152 & 237 & 247 \\
\hline & 248 & 253 & 157 & 148 & 244 & 254 \\
\hline & 256 & 247 & 156 & 152 & 236 & 238 \\
\hline & 249 & 257 & 161 & 162 & 265 & 255 \\
\hline & 263 & 263 & 141 & 155 & 244 & 247 \\
\hline \multirow{5}{*}{95} & 263 & 261 & 152 & 150 & 240 & 245 \\
\hline & 263 & 260 & 155 & 155 & 246 & 252 \\
\hline & 255 & 264 & 154 & 153 & 246 & 244 \\
\hline & 262 & 263 & 159 & 145 & 252 & 253 \\
\hline & 256 & 254 & 137 & 144 & 238 & 228 \\
\hline \multirow{5}{*}{110} & 259 & 254 & 151 & 148 & 247 & 251 \\
\hline & 260 & 261 & 159 & 156 & 226 & 241 \\
\hline & 267 & 260 & 146 & 149 & 246 & 241 \\
\hline & 261 & 256 & 154 & 150 & 239 & 252 \\
\hline & 254 & 250 & 145 & 150 & 242 & 230 \\
\hline \multirow{5}{*}{145} & 250 & 252 & 150 & 155 & 248 & 237 \\
\hline & 250 & 233 & 141 & 134 & 252 & 252 \\
\hline & 252 & 249 & 136 & 140 & 229 & 233 \\
\hline & 247 & 250 & 144 & 135 & 236 & 246 \\
\hline & 252 & 255 & 148 & 152 & 233 & 243 \\
\hline \multirow{2}{*}{157} & 249 & 249 & 142 & 150 & 262 & 249 \\
\hline & 245 & 246 & 152 & 159 & 239 & 232 \\
\hline \multirow{3}{*}{171} & 267 & 252 & 169 & 137 & 260 & 225 \\
\hline & 244 & 247 & 150 & 160 & 243 & 228 \\
\hline & 252 & 251 & 147 & 155 & 225 & 252 \\
\hline \multirow{3}{*}{234} & 246 & 239 & 152 & 147 & 255 & 226 \\
\hline & 253 & 249 & 167 & 153 & 249 & 222 \\
\hline & 248 & 254 & 153 & 167 & 232 & 249 \\
\hline \multirow{2}{*}{322} & 241 & 239 & 150 & 162 & 229 & 248 \\
\hline & 249 & 247 & 158 & 169 & 241 & 230 \\
\hline
\end{tabular}


Using F-test and T-test in Excel software, P-values $>0.05$ were obtained, so the mean difference between the two groups of samples was not statistically significant. So the samples were stable up to 322 days from the date of manufacture. In addition, from the table above, it can be seen that the content of Vitamins B1, B2, B6 changed over time, but the change was not statistically significant during the study period. The cause of the variation may be due to the error of the analytical method.

\subsubsection{Microclimate condition}

The microclimate condition was set up at temperature: $45 \pm 2^{\circ} \mathrm{C}$ and humidity: $75 \pm 5 \%$. The test results are shown in Table 3.

Table 3. The test result of vitamin content

\begin{tabular}{|c|c|c|c|c|c|c|c|}
\hline \multirow{3}{*}{ No } & \multirow{3}{*}{ Days } & \multicolumn{6}{|c|}{ Amount (mg/100g) } \\
\hline & & \multicolumn{2}{|c|}{ Vitamin B1 } & \multicolumn{2}{|c|}{ Vitamin B2 } & \multicolumn{2}{|c|}{ Vitamin B6 } \\
\hline & & $1^{\text {st }}$ & $2^{\text {nd }}$ & $1^{\text {st }}$ & $2^{\text {nd }}$ & $1^{\text {st }}$ & $2^{\text {nc }}$ \\
\hline \multirow{2}{*}{1} & \multirow{2}{*}{30} & 257 & 251 & 148 & 148 & 244 & 233 \\
\hline & & 249 & 251 & 138 & 153 & 253 & 252 \\
\hline \multirow{2}{*}{2} & \multirow{2}{*}{44} & 191 & 184 & 204 & 198 & 227 & 225 \\
\hline & & 193 & 190 & 199 & 186 & 215 & 232 \\
\hline
\end{tabular}

These results were compared to the results of the homogeneity assessment. Pr values $>0.05$ for the content of vitamins, so there is no difference between samples.

The stability of the sample was estimated using the Q10 method. Expected results for vitamin B samples (B1, B2, B6) were stable for 300 days.

\subsection{Certified value and uncertainty}

Samples were sent to 17 laboratories requesting analysis for Vitamin B1, B2, B6. The results were presented in Figure 2.

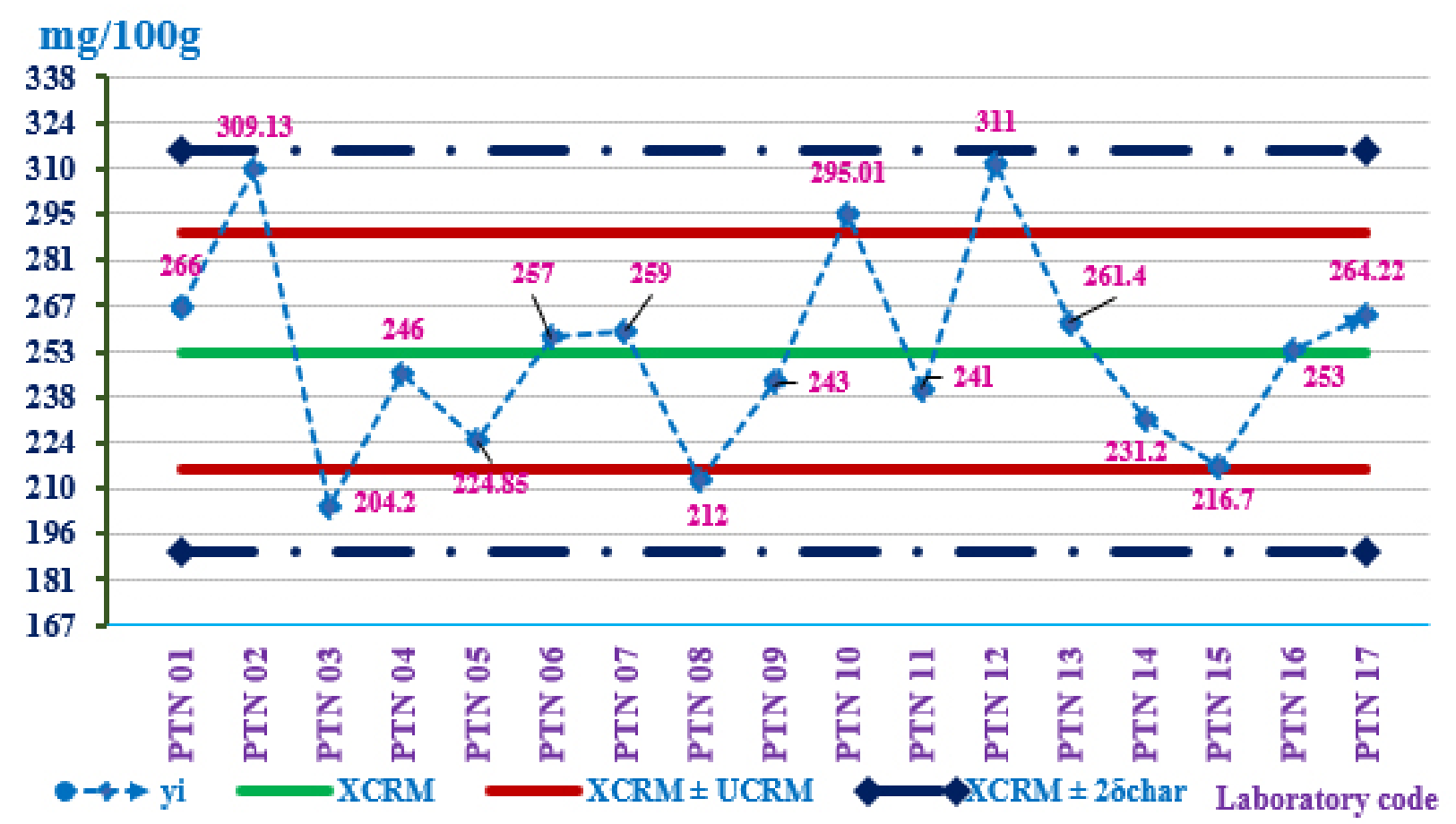

Figure 2. Certified value, uncertainty, and test result of Vitamin B1 content of 17 laboratories

The calculated certified value and uncertainty of Vitamin B1 content was $252.63 \pm 18.408 \mathrm{mg} / 100 \mathrm{~g}$. 


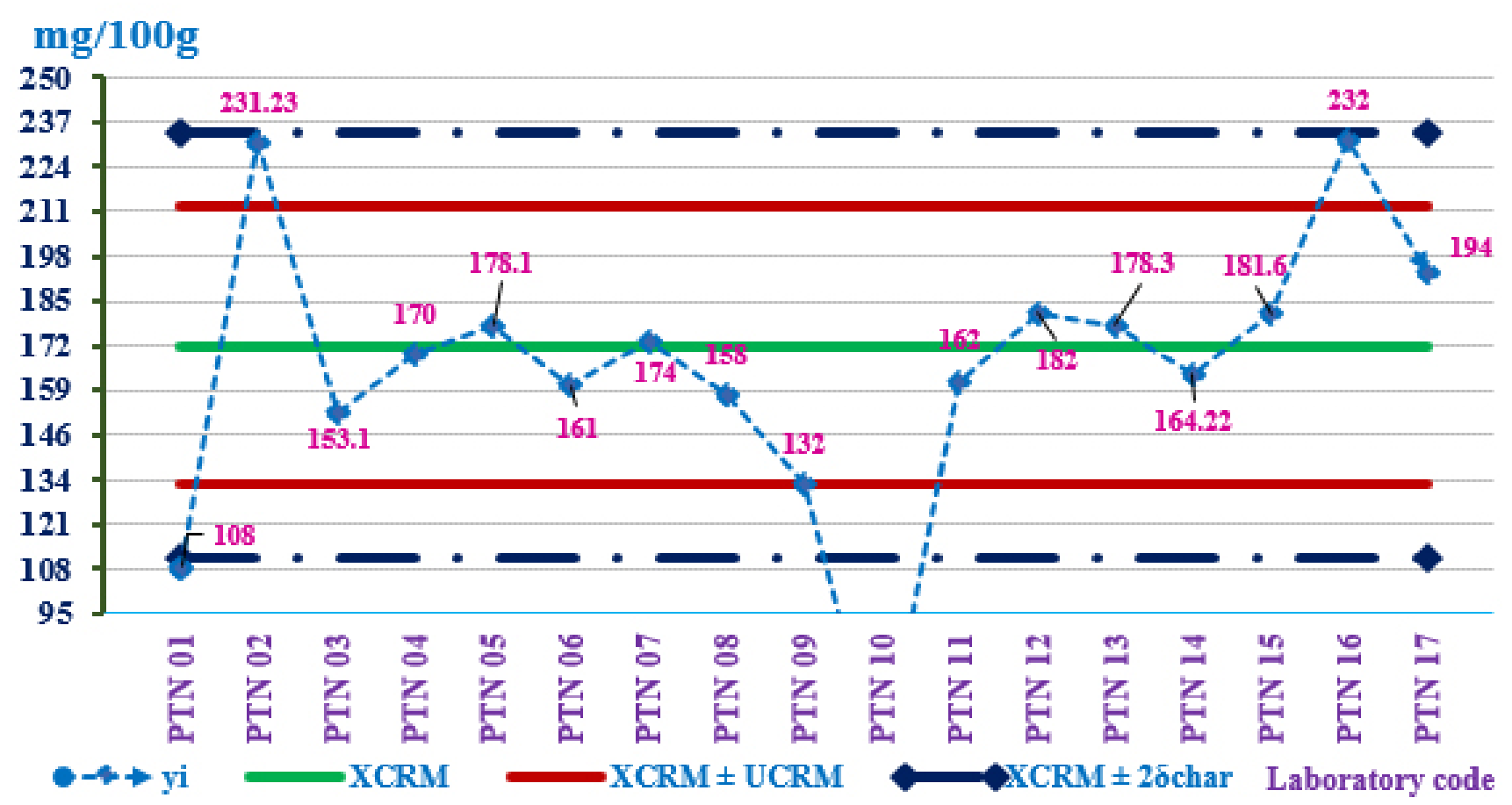

Figure 3. Certified value, uncertainty, and test result of Vitamin B2 content of 17 laboratories

The calculated certified value and uncertainty of Vitamin B2 content was $172.47 \pm 20.103 \mathrm{mg} / 100 \mathrm{~g}$.

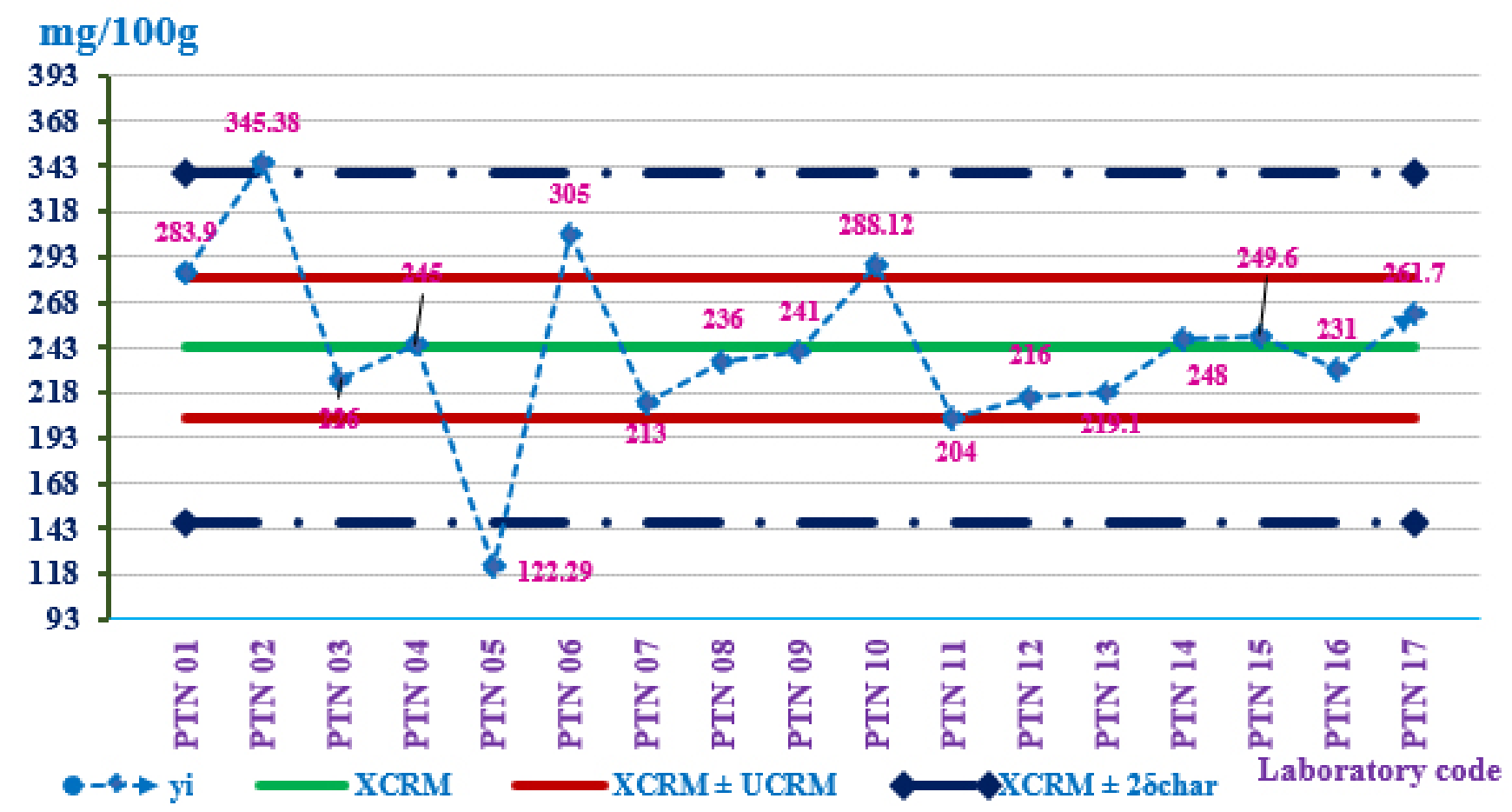

Figure 4. Certified value, uncertainty, and test result of Vitamin B6 content of 17 laboratories

The calculated certified value and uncertainty of Vitamin B6 content was $243.24 \pm 19.119 \mathrm{mg} / 100 \mathrm{~g}$.

This study had not given the exact shelf life of the product due to the limitation of research conditions (only using the microclimate for a short time), so the research team only monitored the stability under the condition of accelerated aging for a short time. We will continue to monitor the product under room temperature conditions at 12, 18, and 24 months to evaluate the product shelf-life; the product is expected to be stable for at least two years. During the expected shelf life, the product will be distributed to a number of laboratories for internal quality control. 


\title{
4. CONCLUSION
}

From the above results, it can be concluded that a health supplement standard sample for analysis of Vitamin B1, B2, B6 has been produced stable for 322 days with certified values of Vitamin B1, B2, B6 corresponds to the uncertainty of $252.63 \pm 18.408 \mathrm{mg} / 100 \mathrm{~g} ; 172.47 \pm 20.103 \mathrm{mg} / 100 \mathrm{~g} ; 243.24 \pm 19.119$ $\mathrm{mg} / 100 \mathrm{~g}$, respectively.

\section{ACKNOWLEDGEMENT}

This study was carried out by the Department of Quality Assurance, National Institute for Food Control, with the project code of TN.20.07 funded by the career development budget of the Institute. In order to complete this study, the research team would like to thank the Department of Nutrients and Food Additives in the process of consulting to implement the project as well as analyzing samples to assess the homogeneity and stability of samples.

\section{REFERENCES}

[1]. ISO 17034:2016 General requirements for the competence of reference material producers.

[2]. TCVN ISO/IEC 17025:2017, General requirements for the competence of testing and calibration laboratories.

[3]. QCVN 12-1:2011/BYT National technical regulation on safety and hygiene for synthetic plastic packaging and tools in direct contact with food.

[4]. ISO Guide 80:2014, Guidance for the in-house preparation of quality control materials (QCMs).

[5]. FAO/WHO expert consultation on human vitamin and mineral requirements, Chapter 3, Thiamin, riboflavin, niacin, vitamin B6, pantothenic acid and biotin, 27-44.

[6]. Circular No. 43/2014/TT-BYT dated November 24, 2014, of the Ministry of Health regulating the management of functional foods.

[7]. ISO Guide 35:2017. Reference materials - Guidance for characterization and assessment of homogeneity and stability.

[8]. ISO/IEC 13528:2015 Statistical methods for use in proficiency testing by interlaboratory comparisons (Second edition 2015-08-01, corrected version 2016-10-15).

\section{Nghiên cứu sản xuất mẫu chuẩn Vitamin B1, B2, B6 trong thực phẩm bảo vệ sức khỏe}

\author{
Nguyễn Thị Hằng, Lê Thị Phương Thảo, Đặng Hữu Cường, \\ Lưu Thị Huyền Trang, Lê Thị Hồng Hảo
}

Viện Kiểm nghiệm an toàn vệ sinh thưc phẩm Quốc gia, Hà Nội, Việt Nam

\section{Tóm tắt}

Vitamin là chất dinh dưỡng thiết yếu thường có trong các sản phẩm thực phẩm nói chung và thực phẩm bảo vệ sức khỏe nói riêng. Để đánh giá chất lượng sản phẩm một cách chính xác phòng thí nghiệm cần sử dụng mẫu chuẩn trong phân tích, đánh giá tay nghề, xác nhận giá trị sử dụng của phương pháp và đảm bảo giá trị sử dụng của kết quả thử nghiệm. Việc sử dụng mẫu chuẩn đóng vai trò quan trọng trong kiểm soát chất lượng kết quả thử nghiệm và là yêu cầu bắt buộc đối với phòng thử nghiệm muốn chứng minh năng lực phù hợp theo yêu cầu của ISO/IEC 17025:2017. Nhu cầu cung cấp mẫu chuẩn cho các phòng thử nghiệm là rất lớn. Tuy nhiên, hiện nay trong nước có rất ít đơn vị sản xuất được mẫu chuẩn, trong khi chi phí mua mẫu chuẩn của các hãng uy tín trên thế giới khá cao. Trong nghiên cứu này, chúng tôi đưa ra được quy trình và tạo được mẫu chuẩn phân tích vitamin nhóm $\mathrm{B}(\mathrm{B} 1, \mathrm{~B} 2, \mathrm{~B} 6)$ được đóng dạng viên nang cứng. Các mẫu chuẩn này đã được đánh giá độ đồng nhất và ổn định trong thời gian 322 ngày. Giá trị chứng nhận được đưa ra phù hợp với nồng độ các chất có trong mẫu thông thường trong thực tiễn. Độ không đảm bảo đo trong khoảng từ 14,5 - 23,3\%. Mẫu có thể được sử dụng để kiểm soát chất lượng nội bộ cho các phòng thử nghiệm trong nước và cũng là tiền đề để tiếp tục nghiên cứu các mẫu chuẩn với nền mẫu và các chỉ tiêu phân tích khác nhau.

Tù̀ khóa: mẫuchuẩn, sảnxuấtmẫuchuẩn, vitamin B1, Vitamin B2, Vitamin B6thựcphẩm bảovệ sứckhỏe. 